\title{
Baseline Values of Cadmium and Zinc in Three Land Uses in a Selected Mapping Unit of the Dry Zone of Sri Lanka
}

\author{
U.K.P.S. Sanjeevani ${ }^{*}$, S.P. Indraratne ${ }^{1}$, S.V.R. Weerasooriya ${ }^{1}$ and U.W.A. Vitharana ${ }^{1}$ \\ Postgraduate Institute of Agriculture \\ University of Peradeniya \\ Sri Lanka
}

\begin{abstract}
Anthropogenic activities change the natural concentrations of soil trace metals in different land uses with varying magnitudes. Establishment of baseline concentration of metals is important in assessing human impact on metal concentrations in soils over time. A study was conducted to compare Cd and $\mathrm{Zn}$ concentrations in different land uses (lowland, upland and non-agricultural) to investigate relationships of $\mathrm{Cd}$ and $\mathrm{Zn}$ with soil properties and to establish geochemical baseline concentrations of the two metals for three land uses of Madawachchiya - Ranorawa - Elayapattuwam - Hurathgama Nawagattegama soil association of the Dry Zone of Sri Lanka. Soils were analyzed for organic carbon (OC), clay, $\mathrm{pH}$, electrical conductivity (EC), and $\mathrm{HNO}_{3}$ acid-soluble $\mathrm{Cd}$ and $\mathrm{Zn}$. Land use had a significant effect $(p<0.05)$ on $C d$ and $\mathrm{Zn}$ contents in soils studied. Accordingly, Cd content of non-agricultural soils was significantly lower than that of both lowland and upland soils. The Zn content of upland soils was significantly higher than that of lowland and non-agricultural soils. A significant correlation between $\mathrm{Cd}$ and $\mathrm{Zn}$ in the non-agricultural soils indicated a possible common source of origin for $\mathrm{Cd}$ and $\mathrm{Zn}$, whereas poor correlations in upland and lowland soils indicated multiple sources of origin. The influence of $O C$, clay \% and EC on metal contents of soils was visible in different land uses. For lowland, upland and non-agricultural soils, the upper baseline limits for Cd were 1.43, $1.47,0.44 \mathrm{mg} / \mathrm{kg}$, respectively, and for $\mathrm{Zn}$ were 39,55 and $38 \mathrm{mg} / \mathrm{kg}$ in, respectively. The results revealed that $C d$ has not reached the contaminated level in the land uses studied, while Zn contamination was evident in some samples of lowland and upland land uses.
\end{abstract}

Keywords: Alfisols, low land, non-agricultural soils, soil properties, up land

\section{INTRODUCTION}

Soils accumulate nutrients, organic and inorganic contaminants under continuous cultivation mainly due to applications of agrochemicals. Those contaminants can reach relatively high concentrations in surface layer of soil, which serves as the root zone for vegetation and also the area with the greatest exposure to animal and human life (Luo et al., 2007). Trace metal pollution in soil is a major concern as soil is a long-term sink for potentially toxic elements (Nicholson et al., 2003; Huang \& Jin, 2008).Trace metal pollution in soil can decrease crop yield and its quality. Moreover, accumulation of trace metals in crops causes potential threats to human health through food chain contamination (Huang \& Jin, 2008). Nicholson et al., (2003) indicated that humans can be exposed to toxic trace metals through direct soil

Department of Soil Science, Faculty of Agriculture, University of Peradeniya, Sri Lanka

Corresponding author: shyamasanjeevani@yahoo.com 
ingestion as well as through consumption of food produced on contaminated soil. Mico et al. (2006) reported that excess use of agro-chemicals, manures and sewage sludge disposal increased the heavy metal concentrations in soil. Further, many researchers have revealed that levels of trace metals such as $\mathrm{Cd}, \mathrm{Zn}, \mathrm{Cu}$ and As contents in soil can increase as they are found in most of the synthetic fertilizers and agrochemicals such as pesticides and herbicides as an impurity or active ingredient (McLaughlin et al., 2000; Huang \& Jin, 2008; Ajayi et al., 2012). Cadmium is well known for causing adverse health effects to humans, but is seldom important as a cause of phytotoxicity in the field. However, $\mathrm{Zn}$ is commonly a deficient and phytotoxic element in soils (Chaney, 2010). In soil environment, Cd and Zn usually occur together and they compete for the same binding places on the colloid surface (Szabo et al., 2008). Further, these elements are usually co-contaminants and have similar properties in soils and plants. Therefore, both elements need to be considered together to understand either Cd or Zn in detail (Chaney, 2010).

Trace metals can be mobilized by changes of environmental conditions such as land use, agricultural inputs and climatic change or by saturation beyond the buffering capacity of the soil (Huang \& Jin, 2008). Szabo et al. (2008) reported that land-use and soil type influence on the amount of $\mathrm{Cd}$ and $\mathrm{Zn}$ uptake by plants. Anthropogenic activities change the natural concentrations of soil trace metals in different land use types with varying magnitudes. Knowledge of metal concentrations for different land use types is of critical importance in assessing human impact on metal concentrations in soils and also in land use planning (Adamu \& Nganje, 2010). There have been several studies on accumulation of trace metals in soils under different land uses in Sri Lanka. A study conducted to investigate the abundances of rare trace metals ( $\mathrm{Ti}, \mathrm{Ga}, \mathrm{As}, \mathrm{Sc}, \mathrm{Zr}, \mathrm{Sn}, \mathrm{Hf}, \mathrm{Th}, \mathrm{U}$ and $\mathrm{Y}$ ) in paddy soils of Sri Lanka proved that those are mainly inherited from soil parent materials (Chandrajith $e t$ al., 2005). Premarathna et al. (2011) reported that some Sri Lankan soils and leafy vegetables in the wet zone exhibit initial evidence of trace metal contamination and emphasized the necessity of systematic investigations to determine the extent of contamination and sources of trace metals in Sri Lankan soils.

In order to distinguish the contributing sources of trace metal accumulation in soils, different statistical techniques have been used (Qishlaqi \& Moore, 2007; Zhang et al., 2008). Correlation analysis enables to identify the strength of linearity between a soil property and trace metals, whereas Principal Component Analysis (PCA) can be used to identify the soil properties which are highly correlated with different trace metals. Correlation analysis between trace metals in soils and fertility parameters help to determine the origin of elevated levels of trace metals in soil (Jia et al., 2010).

Metal background concentration is important in deciding contamination level, risk assessment of contaminants and effects of past land use practices on the levels of inorganic compounds in soils (Holmgren, 1993; Breckenridge \& Crockett, 1998). Therefore, it is important to establish metal background concentrations in different land uses. But, it is difficult to estimate natural background levels of some trace metals in soils due to anthropogenic activities (Shah et al., 2011) and the long distance aerial transport of trace pollutants (Pendias \& Pendias, 2001). Hence, geochemical baseline concentration has been identified as a better variable measurement for trace metal concentrations than the observed ranges (Dudka, 1993) and can be used as a reference to determine the levels of trace metals in different land uses. Therefore, objectives of this study were to compare $\mathrm{Cd}$ and $\mathrm{Zn}$ concentrations in upland, lowland and non-agricultural areas of a selected soil association of the Dry-Zone of Sri Lanka, to investigate their relationship with soil properties and to 
establish geochemical baseline concentrations of $\mathrm{Cd}$ and $\mathrm{Zn}$ to detect the contamination level.

\section{MATERIALS AND METHODS}

\section{Soil sampling}

Soil samples were collected from Madawachchiya - Ranorawa - Elayapattuwa - Hurathgama -Nawagattegama soil association (Fig. 1) in Dry Zone of Sri Lanka (Silva \& Dassanayake, 2010). Study area covered nearly $2000 \mathrm{~km}^{2}$. Surface soil samples at $0-30 \mathrm{~cm}$ depth were collected from randomly selected $5 \mathrm{~km} \times 5 \mathrm{~km}$ grids within the soil association. A total of 103 samples were collected representing three land uses as for low land (38 samples), upland (35 samples) and non-agricultural fields (30 samples). At the time of sampling, the low lands were under paddy while up lands were under vegetables, field crops and other upland crops. Low-land included samples from paddy-paddy cropping system (24\%) and paddyvegetable/field crops cropping system (76\%) whereas upland included 83\% from vegetables, field crops, fruit crops and coconut cultivation. Rest of the upland samples (17\%) were under paddy once in 2-3 years and then rotating with vegetable and field crops (information gathered from farmers). Non-agricultural fields consisted of 4-5 years abandon lands (43\%) and more than 15 years forested area (57\%). Four sub samples were collected to obtain a composite sample at each location.

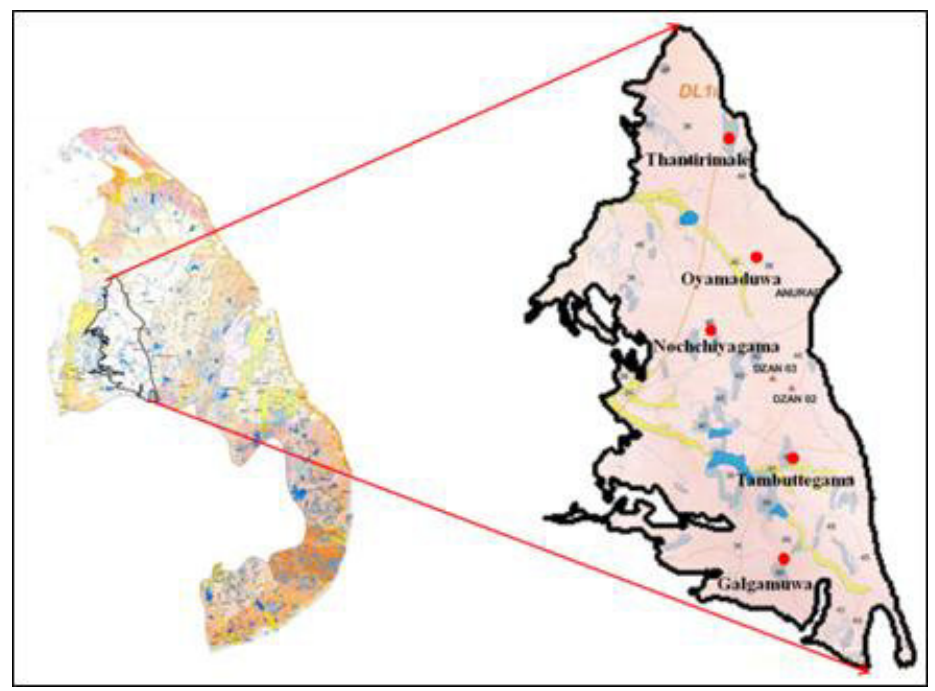

Fig.1. Location of Madawachchiya - Ranorawa - Elayapattuwa - Hurathgama Nawagattegama association in the map of the Dry Zone of Sri Lanka (Source: Mapa et al., 2010).

\section{Laboratory analysis}

Total $\mathrm{Cd}$ and $\mathrm{Zn}$ concentrations were determined according to the method described by

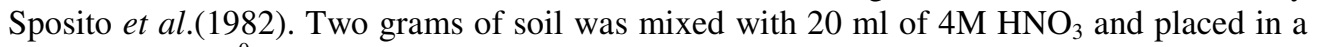
water bath at $80^{\circ} \mathrm{C}$ for four hours. Metal contents were analyzed in extraction after filtering 
using Atomic Absorption Spectrometer (Shimadzu AA 6200). Organic carbon (OC) percentage was determined by acid dichromate oxidation method described by Nelson and Sommer (1996). Soil electrical conductivity (EC) and soil $\mathrm{pH}$ were determined using 1:5 (soil: water) and 1:2.5 (soil: $1 \mathrm{M} \mathrm{KCl)} \mathrm{suspensions,} \mathrm{respectively.} \mathrm{Soil} \mathrm{texture} \mathrm{was} \mathrm{analyzed} \mathrm{by}$ pipette method (Gee \& Bauder, 2002). Standard reference material (SRM-2586 trace elements in soil containing Lead from paint) from National Institute of Standard and Technology was used for the quality control. Microwave digested (EPA method 3050) SRM was used to assure AAS accuracy and SRM was digested similar to soils was used to detect the recovery rate of $4 \mathrm{M} \mathrm{HNO}_{3}$ acid digestion. All the glassware was washed thoroughly after immersing in diluted nitric acid bath and heavy metal grade acids were used for the study. Further, blanks, known standards and laboratory replicates were run with the samples to assure quality control.

\section{Statistical analysis}

Statistical analysis was conducted using SPSS 13.0 and Minitab software. Normality of data was tested using Kolmogorov-Smirnov method. The non-normal data were transferred logarithmically to obtain normal distribution. Both geometric mean (GM) and geometric standard deviation (GSD) were used for the baseline establishment (Equation 1).

$$
G M=\sqrt[n]{x_{1}, x_{2} \ldots x_{n}} \quad G S D=\exp \left(\sqrt{\frac{\sum_{i=1}^{n}\left(\ln \frac{x_{i}}{G M}\right)^{2}}{n}}\right)
$$

where, $n$ indicates the number of observations $\left(\mathrm{x}_{1}, \mathrm{x}_{2} \ldots\right)$

Lower and upper limits of baseline concentrations were defined as $\left(\mathrm{GM} / \mathrm{GSD}^{2}\right)$ and $\left(\mathrm{GM}^{*} \mathrm{GSD}^{2}\right)$ (Chen et al., 1999; Pendias \& Pendias, 2001). Pearson's correlation analysis was used to explore the strength of linearity between trace elements and soil properties. Stepwise regression analysis was performed to identify most influencing soil property on $\mathrm{Cd}$ and $\mathrm{Zn}$ concentration in soils. Based on the correlation matrix, principal component analysis (PCA) was conducted to identify the relationship between soil properties and measured trace metals. Analysis of Variance (ANOVA) was performed to compare mean metal concentrations among the land uses.

\section{RESULTS AND DISCUSSION}

\section{Quality control of trace metal analysis}

Quality control and quality assurance steps were taken for Cd since the expected levels of concentration in the soils were low. Microwave digested sample of the SRM showed the certified value of $2.7 \pm 0.05 \mathrm{mg} / \mathrm{kg}$ ensuring the validity of the data generated for $\mathrm{Cd}$. Further $4 \mathrm{M} \mathrm{HNO}_{3}$ acid digestion showed $2.33 \pm 0.02 \mathrm{mg} / \mathrm{kg}$ recovering $87 \%$ of the Cd present in the SRM. The soil digestion method proposed by Sposito et al. (1982) consumes less time and chemicals than the other methods and extracts all the species of the trace elements except the structural elements in soils. According to Sabiene et al. (2004) most of pollutant inputs are not silicate-bound and pseudo total analysis of strong acid digests, not involving dissolution of silicates is sufficient. 


\section{Soil properties in different land uses}

Low organic carbon percentages (0.12-1.90) were observed in soils collected from three land uses (Table 1). High coefficient of variation in EC for lowland (98\%) and upland soils (99\%) indicated high relative variability compared to that in non-agricultural soils. Mean EC value of non-agricultural soils was lower than that of the lowland and upland soils. However, all soils show no immediate salinity threat. Soil $\mathrm{pH}$ values of three land uses ranged between 4.14 to 8.03 whereas in non-agricultural soils ranged from 4.10 to 7.00 and lower than the other two land uses. The clay percentages in soils of three land uses ranged from 2.2 to 41.7. Clay percentage of the lowland soils had a wide range distribution than the clay percentages of the other two land uses.

Table 1. Basic soil properties of three different land uses.

\begin{tabular}{ccccc}
\hline Soil property & Land use & Observed range & Mean \pm SD & CV\% \\
\hline OC $\%$ & Low land & $0.12-1.41$ & $0.67 \pm 0.30$ & 45.11 \\
& Up land & $0.34-1.90$ & $0.78 \pm 0.35$ & 44.94 \\
& Non-agricultural & $0.28-1.38$ & $0.78 \pm 0.26$ & 33.55 \\
\hline $\mathrm{EC}$ & Low land & $0.02-0.41$ & $0.09 \pm 0.09$ & 97.67 \\
$\mathrm{dS} / \mathrm{m}$ & Up land & $0.02-0.29$ & $0.05 \pm 0.05$ & 98.86 \\
& Non-agricultural & $0.01-0.07$ & $0.03 \pm 0.01$ & 52.48 \\
\hline $\mathrm{pH}$ & Low land & $4.59-8.03$ & $5.96 \pm 0.75$ & 12.56 \\
& Up land & $4.53-6.73$ & $5.38 \pm 0.51$ & 9.51 \\
& Non-agricultural & $4.14-6.96$ & $5.11 \pm 0.46$ & 8.95 \\
\hline Clay\% & Low land & $2.24-41.71$ & $19.5 \pm 11.95$ & 61.29 \\
& Up land & $7.12-36.76$ & $20.31 \pm 6.74$ & 33.20 \\
& Non-agricultural & $4.12-34.92$ & $15.98 \pm 6.94$ & 43.46 \\
\hline
\end{tabular}

CV\% - Coefficient of Variation, SD - Standard Deviation

\section{Cd and $\mathrm{Zn}$ concentrations of different land uses}

Cadmium concentrations of the three land uses ranged from $0.13-1.22 \mathrm{mg} / \mathrm{kg}$ with the lowest range of $0.13-0.44 \mathrm{mg} / \mathrm{kg}$ in non-agricultural soils (Table 2). Observed Cd concentrations of all types of land uses were much lower than the $\mathrm{Zn}$ concentrations. Cadmium concentrations of the three land uses showed a narrow distribution range especially in non-agricultural soils. Both $\mathrm{Cd}$ and $\mathrm{Zn}$ concentrations of the non-agricultural soil were lower than that of other two land uses. 
Table 2. Summary statistics of $\mathrm{Cd}$ and $\mathrm{Zn}$ in surface soils of the three land uses studied (mg/kg).

\begin{tabular}{|c|c|c|c|c|c|}
\hline Element & Land use & $\mathrm{AM}^{*}$ & Median & GM & Observed range \\
\hline \multirow[t]{3}{*}{$\mathrm{Cd}$} & Low land $(n=35)$ & $0.50^{\mathrm{a}}$ & 0.36 & 0.42 & $0.16-1.22$ \\
\hline & Up land $(n=30)$ & $0.55^{\mathrm{a}}$ & 0.55 & 0.49 & $0.14-1.18$ \\
\hline & $\begin{array}{l}\text { Non-agricultural } \\
(\mathrm{n}=25)\end{array}$ & $0.24^{\mathrm{b}}$ & 0.25 & 0.23 & $0.13-0.44$ \\
\hline \multirow[t]{3}{*}{$\mathrm{Zn}$} & Low land $(n=38)$ & $18.35^{\mathrm{a}}$ & 16.07 & 16.66 & $7.44-54.64$ \\
\hline & Up land $(n=35)$ & $25.49^{\mathrm{b}}$ & 23.00 & 23.13 & $8.46-64.40$ \\
\hline & $\begin{array}{l}\text { Non-agricultural } \\
(\mathrm{n}=28)\end{array}$ & $18.94^{\mathrm{a}}$ & 16.39 & 17.65 & $9.30-33.22$ \\
\hline
\end{tabular}

Arithmetic Mean, GM-Geometric Mean and n-number of samples

According to the ANOVA, significant differences $(\mathrm{P}<0.05)$ were observed between land uses for $\mathrm{Cd}$ and $\mathrm{Zn}$. Concentration of $\mathrm{Cd}$ in lowland and upland soils were not significantly different $(\mathrm{P}>0.05)$ whereas the $\mathrm{Cd}$ concentration of non-agricultural soils was significantly lower than that of lowland and upland soils (Table2). Many researchers have reported that phosphorus containing fertilizers are source of $\mathrm{Cd}$ in soils, since $\mathrm{Cd}$ is an impurity of phosphatic fertilizers (Dissanayake \& Chandrajith, 2009). Therefore, Cd can accumulate in cultivated areas compared to non-agricultural areas. The $\mathrm{Zn}$ concentrations of the upland soils were significantly higher than that of both lowland and non-agricultural soils. No significant difference was observed between the $\mathrm{Zn}$ concentrations of lowland and nonagricultural soils. Kumaragamage \& Indraratne (2011) reported that soil Zn concentration in many soils of Sri Lanka were deficient in Zn thus, restricting the optimum growth of plants. The land use explained $22.9 \%$ of the total $\mathrm{Cd}$ variability whereas land use explained only $9.53 \%$ of the total variability of $\mathrm{Zn}$. The land use has an influence on the physical and chemical parameters of the soil and thereby the availability of certain metals (Szabo et al., 2008).

According to Pearson correlation analysis between $\mathrm{Cd}$ and $\mathrm{Zn}$ concentrations in three different land uses, significant positive correlation $(\mathrm{p}<0.05)$ was found for non-agricultural soils $(r=0.49)$. Strong correlations between elements imply similar geochemical controls in the surface environment (Adamu \& Nganje, 2010). Luo et al. (2007) also reported that metals which are poorly correlated with other metals have different sources of origin. Therefore, $\mathrm{Cd}$ and $\mathrm{Zn}$ in non-agricultural area may have a common source. Cadmium and $\mathrm{Zn}$ in lowland and upland soils were not significantly correlated $(\mathrm{P}>0.05)$ suggesting that $\mathrm{Cd}$ and $\mathrm{Zn}$ in soils of upland and lowland can be a resultant of multi sources of origin. As upland and lowland land uses are more disturbed by agricultural activities than the non-agricultural soils, there may be an anthropogenic influence on the concentrations of $\mathrm{Cd}$ and $\mathrm{Zn}$.

Nevertheless, Mico et al. (2006) reported that lithogenic metals are highly correlated with soil properties whereas the anthropogenic metals showed a weak relationship with soil properties as a consequence of their external sources. According to the Pearson correlation analysis of $\mathrm{Cd}$ and soil properties of three land uses, only upland soils showed significant $(r=0.4)$ correlations with OC and clay \% of soils (Table 3$)$. 
Table 3. Pearson correlation coefficient of $\mathrm{Cd}, \mathrm{Zn}$ and soil properties of three land uses.

\begin{tabular}{lcccccccc}
\hline \multirow{2}{*}{ Land use } & \multicolumn{9}{c}{$\mathrm{Cd}$} & \multicolumn{5}{c}{$\mathrm{Zn}$} \\
\cline { 2 - 9 } & $\mathrm{OC}$ & Clay & $\mathrm{EC}$ & $\mathrm{pH}$ & $\mathrm{OC}$ & Clay & $\mathrm{EC}$ & $\mathrm{pH}$ \\
\hline Lowland & -0.14 & 0.05 & 0.17 & 0.03 & $0.38^{*}$ & 0.06 & -0.10 & -0.14 \\
Upland & $0.42^{*}$ & $0.42^{*}$ & -0.23 & -0.36 & $0.62^{* *}$ & $0.39^{*}$ & 0.23 & 0.16 \\
Non-agricultural & -0.11 & 0.20 & 0.30 & -0.04 & 0.13 & $0.42^{*}$ & $0.64^{* *}$ & 0.15 \\
\hline ** Significat at 0.01 la
\end{tabular}

** Significant at 0.01 level (2-tailed), * Significant at 0.05 level (2-tailed)

The zinc concentrations in lowland and upland soils had significant correlations with organic carbon contents in soils (Table 3 ). The non-agricultural soils showed a comparatively strong correlation between EC and $\mathrm{Zn}(\mathrm{r}=0.64)$. Upland and non-agricultural soils showed correlations with clay \% and Zn. Mico et al., (2006) also observed such correlations for Cd and $\mathrm{Zn}$ having different source of origin. According to the stepwise regression analysis, OC content is the most influencing soil property for the $\mathrm{Cd}$ concentration in upland and $\mathrm{Zn}$ concentrations in upland and lowland soils respectively. Further, EC and clay content affect the $\mathrm{Zn}$ concentration in non-agricultural soil. These results further confirmed the results of correlation analysis.

The simple correlation analysis indicated organic carbon content, clay contents and EC influenced on soil $\mathrm{Cd}$ and $\mathrm{Zn}$ concentrations. Organic matter content is one of the most important properties that control the accumulation, mobility and bioavailability of heavy metals in soils (Qishlaqi \& Moore, 2007). Increase in organic matter content can lead to elevate the soil adsorption capacity by which accumulation of heavy metals will be enhanced. Szabo et al. (2008) also reported that $\mathrm{Zn}$ and $\mathrm{Cd}$ contents are affected by the decomposition level of humus materials (quality) as well as clay content.

Correlation analysis provides little information about sources of trace metals in soil (Luo et al., 2007). Therefore, a principal component analysis was performed to identify the soil properties which are correlated with metals in different land uses. Based on the Kaiser criterion, three components in lowland and non-agricultural soils and two components in upland soils were identified (Table 4). Cadmium of upland soil was correlated with the organic carbon and clay \% of soils. No correlations were observed for $\mathrm{Cd}$ and soil properties in lowland and non-agricultural soils.

Table 4. Rotated component matrix of $\mathrm{Cd}$ and soil properties in three land uses.

\begin{tabular}{lcccccccc}
\hline & \multicolumn{3}{c}{ Lowland } & \multicolumn{3}{c}{ Upland } & \multicolumn{3}{c}{ Non-agricultural } \\
& PC 1 & PC 2 & PC 3 & PC 1 & PC 2 & PC 1 & PC 2 & PC 3 \\
\hline Cumulative \% & & & & & & & & \\
of variance & 32.23 & 57.35 & 78.93 & 37.31 & 69.97 & 33.35 & 65.43 & 88.96 \\
OC & -0.088 & 0.657 & -0.395 & $\mathbf{0 . 7 9 8}$ & -0.029 & 0.276 & 0.827 & -0.254 \\
Clay & -0.116 & 0.856 & 0.220 & $\mathbf{0 . 8 3 9}$ & 0.065 & -0.01 & 0.887 & 0.266 \\
EC & 0.851 & -0.300 & 0.101 & 0.072 & 0.882 & 0.871 & 0.365 & 0.311 \\
pH & 0.928 & 0.038 & 0.013 & -0.192 & 0.833 & 0.959 & 0.011 & -0.107 \\
Cd & 0.063 & 0.016 & 0.930 & $\mathbf{0 . 6 9 5}$ & -0.394 & 0.055 & 0.022 & 0.966 \\
\hline
\end{tabular}

Extraction Method: Principal Component Analysis. Rotation Method: Varimax with Kaiser Normalization, PCprincipal component. 
The $\mathrm{Zn}$ contents of upland soils correlated with organic carbon and clay \% whereas $\mathrm{Zn}$ contents of lowland soils were correlated only with organic carbon as in simple correlation analysis (Table 3). In the PCA based on the Kaiser criterion, two components were identified in lowland, upland and non-agricultural soils (Table 5). In the PCA, significant correlations were observed for $\mathrm{Zn}$ contents in non-agricultural soils with clay contents, EC and organic carbon contents, whereas in correlation analysis it was only with clay contents and EC.

Table 5. Rotated component matrix of $\mathrm{Zn}$ and soil properties in three land uses.

\begin{tabular}{lcccccc}
\hline & \multicolumn{2}{c}{ Lowland } & \multicolumn{2}{c}{ Upland } & \multicolumn{2}{c}{ Non-agricultural } \\
& PC 1 & PC 2 & PC 1 & PC 2 & PC 1 & PC 2 \\
\hline $\begin{array}{l}\text { Cumulative \% } \\
\text { of variance }\end{array}$ & 34.18 & 62.63 & 40.52 & 72.76 & 39.65 & 71.43 \\
OC & -0.170 & 0.814 & 0.879 & -0.108 & $\mathbf{0 . 6 7 8}$ & 0.236 \\
Clay & -0.378 & 0.306 & 0.763 & -0.016 & $\mathbf{0 . 9 0 6}$ & -0.156 \\
EC & 0.913 & -0.086 & 0.118 & 0.870 & $\mathbf{0 . 5 5 0}$ & 0.749 \\
pH & 0.838 & -0.034 & -0.062 & 0.884 & -0.021 & 0.919 \\
Zn & -0.004 & 0.811 & 0.808 & 0.246 & $\mathbf{0 . 6 3 2}$ & 0.322 \\
\hline
\end{tabular}

Extraction Method: Principal Component Analysis. Rotation Method: Varimax with Kaiser Normalization, PCprinciple component.

\section{Baseline concentrations of $\mathrm{Cd}$ and $\mathrm{Zn}$ in different land uses}

Chen et al. (1998) reported that the calculated baseline concentrations, assuming log normality of the elemental distribution, better represent the natural level of elements in soils, as the distorting effects of a few high values are minimized. The log probability plot of the $\mathrm{Cd}$ and $\mathrm{Zn}$ in three different land uses showed a near linear trend (Fig. 2). Therefore, according to Chen et al. (2000) and Zhang et al., (2008) the data can be assumed to be within a single statistical population and can be used for current baseline establishment.
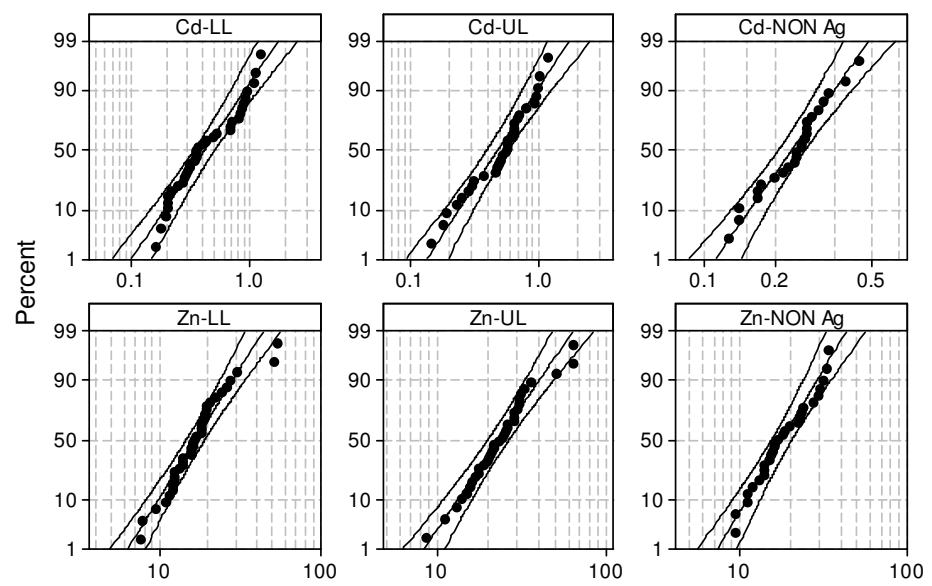

Fig. 2. Log probability plots of $\mathrm{Cd}$ and $\mathrm{Zn}$ in different land uses (LL-Lowland, ULUpland, NON Ag-Non-agricultural). 
The upper baseline limits for $\mathrm{Cd}$ in lowland, upland and non-agricultural soils were 1.43, 1.47 and $0.44 \mathrm{mg} / \mathrm{kg}$ respectively (Table 6). The upper limit of the baseline can be used to assess the possible metal contamination in soil (Chen et al., 1999). In this study, observed Cd concentrations were below the upper baseline value for respective land uses.

Table 6. Baseline ranges of $\mathrm{Cd}$ and $\mathrm{Zn}$ in different land uses (mg/kg).

\begin{tabular}{llcc}
\hline Metal & \multicolumn{2}{c}{ Land use } & \multicolumn{2}{c}{ Baseline range } \\
& & Lower limit & Upper limit \\
\hline Cd & Low land & 0.12 & 1.43 \\
& Up land & 0.16 & 1.47 \\
& Non-agricultural & 0.12 & 0.44 \\
\hline Zn & Low land & 7 & 39 \\
& Up land & 9 & 55 \\
& Non-agricultural & 8 & 38 \\
\hline
\end{tabular}

The upper baseline limits for $\mathrm{Zn}$ in lowland, upland and non-agricultural soils were 39, 55 and $38 \mathrm{mg} / \mathrm{kg}$ respectively (Table 6). Among the observed $\mathrm{Zn}$ concentrations, two samples from lowland and two samples from upland exceeded the established upper limit of the baseline range. This can be due to application of fertilizers and $\mathrm{Zn}$ containing pesticides. As $\mathrm{Zn}$ is a micro nutrient, it is added to soil intentionally. Chaney (2010) reported that sequential changes in flooded soils also affect the phytoavailability of $\mathrm{Zn}$. Water logging resulted in the release of manganese and iron from the oxide bound reservoirs to the soluble, exchangeable and inorganic reservoirs, and increase in cadmium, lead and zinc in the inorganic reservoir has been observed (Bjerre \& Schierup, 1985). Majority of the soil have not exceeded the upper limit of the baseline range for respective $\mathrm{Cd}$ and $\mathrm{Zn}$.

\section{CONCLUSIONS}

The present study revealed that the land use has a significant effect on $\mathrm{Cd}$ and $\mathrm{Zn}$ contents in selected soils. The $\mathrm{Cd}$ content of non-agricultural soil was significantly lower than that of the lowland and upland, indicating the influence of anthropogenic activities on $\mathrm{Cd}$ enrichments in cultivated lands. The $\mathrm{Cd}$ contents in lowland and upland soils were not significantly different. The $\mathrm{Zn}$ contents of upland soils were significantly higher than that of both lowland and non-agricultural soils. The $\mathrm{Zn}$ concentrations in lowland and non-agricultural soils were not significantly different. Simple correlation analysis and principal component analysis identified that organic carbon, clay content and electrical conductivity are the soil properties influencing $\mathrm{Cd}$ and $\mathrm{Zn}$ contents in soils in different land uses. A significant positive correlation between $\mathrm{Cd}$ and $\mathrm{Zn}$ in non-agricultural soils suggested that origin of $\mathrm{Cd}$ and $\mathrm{Zn}$ is a common source, probably lithogenic, whereas origin of $\mathrm{Cd}$ and $\mathrm{Zn}$ in lowland and upland soils cannot be traced to a common source, indicating effects of anthropogenic only and mixed (lithogenic and anthropogenic) of both sources.

Established upper baseline value for Cd suggested that soil Cd contents in the three land uses have not reached the contamination level within the soil association. Further, the observed $\mathrm{Zn}$ contents were below the calculated upper limit of baseline ranges of $\mathrm{Zn}$ except in a few samples in lowland (two) and upland (two). 


\section{ACKNOWLEDGEMENT}

Authors wish to acknowledge the National Research Council for funding the research through NRC 11_166 grant. Heads of the Departments of Soil Science, and Food Science and Technology, Faculty of Agriculture, University of Peradeniya, Sri Lanka are acknowledged for providing analytical facilities. The technical officers of both Departments are highly appreciated for the support provided during the analysis.

\section{REFERENCES}

Adamu, C.L. and Nganje, T.N. (2010). Heavy metal contamination of surface soil in relationship to land use patterns: A case study of Benue State, Nigeria. Materials Sciences and Applications.1, 127-134.

Ajayi, S.O., Odesanya, B.O., Avwioroko, A.O., Adebambo, G.S. and Okafor, B. (2012). Effects of long term fertilizer use on trace metal levels of soils in a farm settlement. Journal of Agricultural Research and Development. 2, 44-51.

Breckenridge, R.P. and Crockett, A.B. (1998). Determination of background concentrations of inorganics in soils and sediments at hazardous waste sites. Environmental Monitoring and Assessment. 51, 621-656.

Bjerre, G.K. and Schierup, H.H. (1985). Influence of water logging on availability and uptake of heavy metals by oat grown in different soils. Plant and Soil. 88, 45-56.

Chandrajith, R., Dissanayake, C.B. and Tobschall, H.J. (2005). The abundances of rarer trace elements in paddy (rice) soils of Sri Lanka, Chemosphere. 58, 1415-1420.

Chaney, R.L. (2010). Cadmium and Zinc. pp. 409-439. In: Peter S. Hooda (Ed.) Trace elements in soils. A John Wiley and Sons, Ltd., Publication, United Kingdom.

Chen, M., Ma, L.Q., Hoogeweg, C.G. and Harris, W.G. (2001). Arsenic background concentrations in Florida, U.S.A. Surface Soils: Determination and Interpretation. Environmental Forensics. 2, 117-126.

Chen, M., Ma, L.Q. and Harris, W.G. (1999). Baseline concentrations of 15 trace elements in Florida surface soils. J. Environ. Qual. 28, 1173-1181.

Chen, M., Ma, L.Q. and Harris, W.G. (1998). Assessment of P concentrations in different types of Florida surface soils. Proc. Soil Crop Sci. Soc. Fla. 58, 16-18.

Dissanayake, C.B. and Chandrajith, R. (2009). Phosphate mineral fertilizers, trace metals and human health, J. Natn. Sci. Foundation, Sri Lanka. 37(3), 153-165.

Dudka, S. (1993).Baseline concentrations of As, Co, Cr, Cu, Ga, Mn, Ni and Se in surface soils, Poland. Appl. Geochem. 2, 23-28.

Gee, G.W. and Bauder, J.W. (2002). Particle size analysis. pp. 383-411. In: Clute, A. (Ed.). Methods of soil analysis, Part 1. Physical and mineralogical methods. Agronomy monograph 9. American Society of Agronomy, Medison, WI. 
Holmgren, G.G.S., Meyer, M.W., Chaney, R.L. and Daniels, R.B. (1993). Cadmium, Lead, Zinc, Copper and Nickel in Agricultural Soils of the United States of America. J. Environ. Qual. 22, 335-348.

Huang, S.W. and Jin, J.Y. (2008). Status of heavy metals in agricultural soils as affected by different patterns of land use: Environ. Monit. Assess. 139, 317-327.

Jia, L., Wang, W., Li, Y. and Yang, L. (2010). Heavy metals in soil and crops of an intensively farmed area: A case study in Yucheng City, Shandong Province, China, Int. J. Environ. Res. Public Health. 7, 395-412

Kumaragamage, D and Indraratne, S.P. (2011).Systermatic approach to diagnosing fertility problems in soils of Sri Lanka. Communications in Soil Science and Plant Analysis. 42, 2699-2715.

Luo, W., Lu, Y., Giesy, J.P., Wang, T., Shi, Y., Wang, G. and Xing, Y. (2007). Effects of land use on concentrations of metals in surface soils and ecological risk around Guanting Reservoir, China: Environ Geochem Health. 29, 459-471.

Mapa, R.B., Somasiri, S. and Dassanayake, A.R. (2010). Soils of the dry-zone of Sri Lanka. Special publication 7, Soil Science Society of Sri Lanka.

McLaughlin, M. J., Hamon, R. E., McLaren, R. G., Speir, T. W. and Rogers S. L. (2000). A bioavailability-based rationale for controlling metal and metalloid contamination of agricultural land in Australia and New Zealand. Aust. J. Soil Res. 38, 1037-1086.

Mico C., Recatala, L., Peris, M. and Sanchez, J. (2006). Assessing heavy metal sources in agricultural soils of a European Mediterranean area by multivariate analysis. Chemosphere. $65,863-872$.

Nelson, D.W. and Sommer L. E. (1996). Total organic carbon and organic matter. pp. 361404. In: Sparks, D.L. (Ed.) Method of Soil Analysis, Part 3, Chemical Methods: American Society of Agronomy, soil science society of America, Madiston, Wiscons, USA.

Nicholson, F. A., Smith, S. R., Alloway, B. J., Carlton-Smith, C. and Chambers, B. J. (2003). An inventory of heavy metals inputs to agricultural soils in England and Wales: The Science of the Total Environment. 311, 205-219.

Pendias, A, K. and Pendias, H. (2001). The Anthroposphere (in) Trace elements in soil and plants. 3rd ed., CRC press, Washington.

Premarathna, H.M.P.L., Hettiarachchi, G.M. and Indraratne, S.P. (2011). Trace metal concentration in crops and soils collected from intensively cultivated areas of Sri Lanka, Pedologist. 54(3), 230-240.

Qishlaqi, A. and Moore, F. (2007). Statistical analysis of accumulation and sources of heavy metals occurrence in agricultural soils of Khoshk river banks, Shiraz, Iran, American Eurasian J. Agric. \& Environ. Sci. 2(5), 565-573. 
Sabiene, N, Brazauskiene, D.M. and Rimmer, D (2004). Determination of heavy metal mobile forms by different extraction methods, Ekologija. 36-41.

Shah, M. H., Iqbal, J., Shaheen, N., Khan, N., Choudhary, M.A. and Akhter, G. (2011). Assessment of background levels of trace metals in water and soil from a remote region of Himalaya [on line]. [Accessed on 13.12.2011]. Available at www.ncbi.nlm.nih.gov/pubmed/21625922

Silva, G.G.R.D and Dassanayake, A.R., (2010). Dry-zone soils derived from erosional surface. pp 79-176.In: Mapa, R.B., Somosiri, S. and Dassanayake, A,R. (Ed.) Soils of the dry-zone of Sri Lanka special publication 7, Soil Science Society of Sri Lanka.

Sposito, G., Hotzclaw, K.M., LeVesque-Madore, C.S. and Johnston, C.T. (1982). Tracemetal chemistry in arid-zone field soils amended with sewage-sludge. Comparative study of the fulvic acid fraction. Soil Sci. Soc. Am. J. 46, 265-270.

Szabo, S. Agoston, C., Braun, M., Keresztúri, P. and Szabo, G. (2008). Cadmium and zinc uptake of rye-grass as related to soil type and different land use: Alps-Adria Scientific Workshop. 327-430.

Zhang, H.H., Li, F.B., Wu, Z.F., Li, D.Q., Xu, D.R. and Yuan, H.X. (2008). Baseline Concentrations and spatial distribution of trace metals in surface soils of Guangdong Province, China. J. Environ. Qual. 37, 1752-1760. 